\title{
KARAKTERISTIK UNIVERSAL PELAYANAN PUBLIK: SEBUAH TINJAUAN TEORITIK ${ }^{1}$
}

\author{
Alamsyah \\ Dosen di Jurusan Ilmu Administrasi Negara FISIP Universitas Sriwijaya \\ Kampus FISIP Unsri Indralaya, Jl. Lintas Timur Sumatera Km. 32, \\ Kelurahan Timbangan, Kecamatan Indralaya Utara, \\ Kabupaten Ogan Ilir, Sumatera Selatan \\ Email: gezalian@gmail.com
}

\begin{abstract}
Nowdays, theoretichal debates on public services have been dominated by the changing ideas from New Public Management to governance, from market-oriented public services to citizen-oriented public service. It will be a never ending process because country and market life in mutualism symbiosis. They need each other. Starting from theoritical ideas and public service praxis in several countries, this paper construct a concept of universal characteristics of public services, which is, public service should be serve public value and public interest, they are not value free, they must be partipatory and empowering, fast, flexible, and friendly, economically, social and ecological justice oriented, accountable, resposive, transparent, acting based on ethical norms and laws. Although public service has universal characteristics but contextual and situational factor still influence praxis of public service in many countries.
\end{abstract}

Keywords: government, public service, public interest.

\section{Intisari}

Hari ini, perdebatan teoritik tentang pelayanan publik didominasi pergeseran New Public Management ke governance, dari pelayanan publik berorientasi pasar ke warga negara. Perdebatan ini tidak akan pernah selesai karena negara dan pasar sesungguhnya saling membutuhkan. Bertolak dari pemikiran teoritik dan praxis pelayanan publik di beberapa negara, makalah ini mengkonstruksi konsep karakteristik universal pelayanan publik (pelayanan publik berorientasi kepentingan dan nilai-nilai publik, para pelayan publik tidak boleh bebas nilai, pelayanan publik harus partisipatif dan memberdayakan, fast, flexible, dan friendly, ekonomis, berkeadilan sosial dan ekologis, akuntabel, responsif dan transparan, tindakan para pelayan publik mempertimbangkan etika tertentu, sistem dan proses pelayanan publik

${ }^{1}$ Naskah diterima: 31 Mei 2011, revisi kesatu: 5 Juni 2011, revisi kedua: 18 Oktober 2011 
dibangun atas dasar aturan, hukum, dan kesepakatan tertentu). Meskipun bersifat universal, tetapi faktor-faktor kontekstual dan situasional tetap mempengaruhi wajah pelayanan publik di setiap negara. Makalah diakhiri dengan implikasi teoritis bagi pemikiran dan praxis pelayanan publik di Indonesia.

Kata kunci: pemerintah, pelayanan publik, kepentingan publik.

\section{A. PENDAHULUAN}

Tahun 2011, kita menyaksikan peristiwa luar biasa di Timur Tengah. Tepatnya di Tunisia, Yaman, dan Libya. Judul besarnya adalah pergolakan politik yang menunjukkan perlawanan sekelompok warga negara terhadap rezim status quo. Dengan asumsi bahwa peristiwa di atas merupakan transisi demokrasi, maka apa yang terjadi di Tunisia, Yaman, dan Libya semakin menguatkan tesis tentang nilai-nilai demokrasi yang bersifat universal. Aspirasi demokrasi muncul di negara-negara Timur Tengah dan Afrika Utara yang jelas berbeda dengan negara-negara Barat. Demokrasi, dengan beragam variannya, merupakan barang publik global (global public goods) yang dibutuhkan banyak orang.

Dengan logika yang sama, kita bisa mengatakan bahwa karena pelayanan publik dibutuhkan banyak orang, maka sangat mungkin ada karakteristik universal pelayanan publik. Penulis kira, persoalan inilah yang terlupakan dalam perkembangan pemikiran tentang pelayanan publik. Kita seolah terseret arus dalam dinamika pemikiran itu sendiri tanpa menyadari bahwa setiap tahapan perkembangan pemikiran tentang pelayanan publik di beragam belahan dunia telah menyumbang satu dan/atau beberapa puzzle yang bisa digunakan untuk mengkonstruksi karakteristik universal pelayanan publik.

Di Tanah Air, kasus pasien yang bernama Prita, polisi yang bernama Norman, dan lagu Udin sedunia, perpustakaan sastra H. B. Jassin, merupakan kepingan puzzle yang seharusnya turut dipertimbangkan dalam membangun sistem pelayanan publik komporer di Indonesia. Kasuskasus ini menunjukkan bagaimana kekuatan dunia internet dan media massa di Tanah Air memiliki kontribusi positif terhadap perbaikan pelayanan publik (kasus Prita), perubahan persepsi warga negara terhadap aparatur pelayanan publik (kasus Norman), kekuatan media massa dan psikologi yang mampu merubah keputusan para pembuat kebijakan (kasus Udin), dan lebih peduli terhadap persoalan yang selama ini mereka abaikan (kasus Jassin).

Prita, Norman, Udin, dan Jasin sesungguhnya merepresentasikan dunia private. Mereka bertindak untuk memenuhi motif pribadi yang privateoriented. Tetapi, sesuatu private ini bisa memicu lahirnya persoalan publik yang bersinggungan dengan nilai-nilai kepentingan publik. Peristiwa ini menujukkan bahwa garis privatepublic bagi masyarakat Indonesia sangat kabur. Ketika Prita dianiaya akibat tindakan sewenang-wenang, Norman dihukum hanya gara-gara 
menyanyi, lagu Udin diharamkan karena tafsiran sepihak, dan koleksi Jasin diabaikan begitu saja, warga negara Indonesia berteriak.

Kasus-kasus di at a s menunjukkan warga negara Indonesia masih memiliki kepedulian dan kekuatan partisipatoris terhadap perjalanan republik ini. Sayangnya, rasa kepedulian dan partisipasi yang dilembagakan seringkali gagal melahirkan partisipasi yang membawa perubahan. Belajar dari kasus Prita, Norman, Udin, dan Jasin di atas, mungkin sudah saatnya kita membangun mekanisme partisipasi spontan yang massif dalam sistem pelayanan publik di Indonesia. Untuk sampai pada titik ini, perlu ada perubahan mindset multipihak tentang pelayanan publik itu sendiri. Makalah ini mewacanakan perubahan mindset itu.

Sebagai starting point untuk menyelesaikan tugas di atas, penulis mulai dengan membangun defenisi tentang pelayanan publik. Uraian dilanjutkan dengan literatur review tentang pelayanan publik. Pada tahap ini, akan diuraikan perspektif teoritik tentang pelayanan publik. Setelah berkelana di dunia teoritik, penulis akan mengajak pembaca untuk melihat fakta empiris tentang pelayanan publik di beberapa negara, tak terkecuali di Tanah Air. Pada tahap ini, penulis ingin menunjukkan bahwa meskipun sosok pelayanan publik itu beragam, tapi ia memiliki beberapa kesamaan . Gabungan ide-ide teoritik dan beberapa kesamaan pada level empiris akan dijadikan raw data untuk mengkonstruksi konsep karakteristik universal pelayanan publik. Terakhir, penulis akan mendiskusikan implikasi konsep karakteristik universal pelayanan publik bagi pelayanan publik di Indonesia.

\section{B. DEF I N IS I PELAYANAN PUBLIK}

M a s y r a k a t moder $n$ berkembang semakin kompleks. Sadar atau tidak, seseorang semakin tergantung dengan keberadaan orang lain (the others). Orang lain tersebut bisa individu (saudara, sahabat, rekan sekantor). Bisa juga sekelompok orang yang terorganisir secara sistematis dalam kerangka kelembagaan tertentu (misalnya, Pasar Tanah Abang di Jakarta, Pasar Beringharjo di Jogjakarta, dan Pasar Cinde di Palembang). Orang lain tersebut bisa berbentuk otoritas ekonomi raksasa (misalnya, Microsoft, Toyota, Nokia, Blackberry, Panasonic) dan/atau otoritas politik (misalnya, D P R / D P D / D P R D , Presiden/Menteri/Gubernur/Bupati, lembaga kementerian pemerintah pusat, lembaga departemen dan nondepartemen di pemerintah pusat dan satuan kerja perangkat daerah). Terakhir, orang lain tersebut bisa berbentuk sekumpulan orang yang digerakkan atas dasar prinsip kerelawanan dalam rangka memenuhi kebutuhan anggotanya (misalnya, kelompok kematian, kelompok tani, klub olahraga, dan sebagainya).

Manusia modern bergantung dengan orang lain karena banyak kebutuhan hidupnya sehari-hari tak bisa disediakan oleh tangannya sendiri. Semua kebutuhan manusia modern, baik kebutuhan papan, sandang, dan 
pangan, terpenuhi akibat intervensi orang lain. Karena manusia modern tidak bisa mengontrol secara langsung apa yang dia konsumsi, faktor kepercayaan (trust) menjadi sangat penting bagi keberlanjutan prosesproses sosial ini. Kepercayaan adalah semen bagi kehidupan kolektif manusia. Sistem masyarakat modern memaksa kehidupan manusia saling bergantung satu sama lain. Meskipun penduduk kota tidak memiliki sawah, mereka tetap bisa mengkonsumsi beras karena pemerintah memastikan ketersediaan bahan pangan melalui serangkaian tindakan tertentu. Meskipun seorang petani tidak memiliki pengetahuan elektronika, ia bisa membeli dan menggunakan telepon genggam karena pasar menyediakan peralatan tersebut. Tetapi, pasar tidak selalu bisa menyediakan kebutuhan barang dan jasa manusia karena fakta kegagalan pasar.

Dalam kacamata ilmu ekonomi murni, kegagalan pasar lahir karena barang publik dan ekternalitas (Bellinger, 2007: 96- 113). Sedangkan dari sudut pandang ekonomi-politik, kegagalan pasar berbentuk problems of interdependence (pasar tidak mampu mengkoordinasikan keputusankeputusan yang diambil perusahaanperusahaan swasta dan eksternalitas kontrak-kontrak bisnis perusahaan swasta), problems of exclusion (pasar membangun kondisi/prasyarat tertentu agar warga bisa berpartisipasi. Ketika kesejahteraan warga bergantung kepada pasar, maka mereka yang tidak memenuhi kondisi/prasyarat tersebut tidak akan bisa mencapai kesejahteraanya), dan problems of inequality (diantara mereka yang berpartisipasi di pasar, beberapa diantaranya mendapatkan harga yang lebih baik ketimbang yang lainnya) (Levin, 1995: 164-165).

Karena pasar tidak sempurna, negara mengintervensinya melalui pelayanan publik. Dengan kata lain, pelayanan publik ada karena ia merupakan instrumen pencapaian tujuan-tujuan konstitutional negara. Menurut O'Toole (2006), beberapa filsuf menggunakan istilah berbeda, tetapi memiliki makna sama untuk menggambarkan tujuan akhir berdirinya negara. Plato dan Aristoteles, misalnya, menggunakan istilah common interest dan good life. St Thomas Aquinas menggunakan istilah common good. Jean Jacques Rosseau menggunakan istilah the general will. Istilah-istilah ini (common interest, common good, dan the general will) sepadan dengan istilah public interest yang populer saat ini.

Selanjutnya, secara leksikal, menurut Kamus Webster's New World College (1996: 1226), pelayanan berarti (1) work done for a master or feodal lord; dan (2) work done or duty performed for another or others. Pengertian ini mengandung empat dimensi pelayanan, yakni: yang dilayani, yang melayani, sumber legitimasi pelayanan, dan bentuk aktivitas pelayanan (yang mengandung serangkaian tugas) itu sendiri. Sedangkan untuk istilah public service, Kamus Webster's New World College Dictionary (1996: 1.087) memberikan dua makna, yakni: (a) employment by the government, especially through civil service employee; (b) some service 
performed for the public with no direct, charge, as by a private corporation.

Tentu saja, defenisi leksikal ini terlalu berpihak kepada negara dan mengabaikan peran institusi pasar dan masyarakat sipil yang memiliki kapasitas untuk melayani publik. Penulis sendiri cenderung mendefenisikan pelayanan publik sebagai: setiap aktivitas pelayanan yang dilakukan pemerintah, individu, organisasi, dan yang lainnya (the others) dalam rangka merespon tuntutan individu, kelompok, organisasi, dan yang lainnya (the others) yang bersinggungan dengan kepentingan keseluruhan populasi penduduk. Menurut defenisi ini, siapa yang melayani tidaklah penting. Yang penting adalah apa dan bagaimana kepentingan keseluruhan populasi penduduk direspon aktor-aktor yang berpotensi menjadi pelayan publik.

Sebagai perbandingan, Pasal 1 Undang-Undang Nomor 25 Tahun 1999 tentang Pelayanan Publik mengartikan pelayanan publik sebagai kegiatan atau rangkaian kegiatan dalam rangka pemenuhan kebutuhan pelayanan sesuai dengan peraturan perundang-undangan bagi setiap warga negara dan penduduk atas barang, jasa, dan/atau pelayanan administrasi yang disediakan penyelenggara pelayanan publik. Penyelenggara pelayanan publik itu bisa institusi penyelenggara negara (eksekutif, legislatif, yudikatif, aparat militer, dan birokrasi pemeirntah), korporasi (swasta, korporasi milik negara, dan korporasi milik publik), lembaga independen yang dibentuk berdasarkan undangundang untuk kegiatan publik, dan badan hukum lain yang dibentuk semata-mata untuk kegiatan pelayanan publik (misalnya, asosiasi masyarakat sipil yang berbentuk yayasan).

\section{PERSPEKTIF TEORITIK TENTANG PELAYANAN PUBLIK}

Jika pelayanan publik didefenisikan sebagai setiap aktivitas pelayanan yang dilakukan pemerintah, individu, organisasi, dan yang lainnya (the others) dalam rangka merespon tuntutan individu, kelompok, organisasi, dan yang lainnya (the others) yang bersinggungan dengan kepentingan keseluruhan populasi penduduk, maka ada empat dimensi yang terkandung dalam defenisi ini, yakni: yang dilayani, yang melayani, sumber legitimasi pelayanan, dan bentuk aktivitas pelayanan (yang mengandung serangkaian tugas) itu sendiri.

Pertanyaan pertama yang perlu dijawab teori pelayanan publik adalah siapa sesungguhnya yang dilayani pelayanan publik. Persoalan ini melahirkan preposisi sederhana: pelayanan publik melayani publik. Siapakah publik itu? Sebagian menganggap publik merujuk populasi penduduk secara keseluruhan. Ia bisa juga dimaknai sebagai sekelompok orang yang berdomisili di wilayah geografis tertentu yang merupakan satu kesatuan daerah pemilihan Pemilu dan sekelompok orang yang memiliki karakter, kebutuhan, kepentingan, dan ketertarikan isu yang sama (misalnya, kelompok kepentingan) (Franklin, 2001: 126). Dalam perspektif instrumentalis, publik diartikan sebagai setiap orang yang berstatus 
sebagai konsumen barang dan jasa publik (Lubienski, 2003: 478). Bertolak dari argumentasi ini publik dapat dimaknai sebagai sekelompok orang, baik sebagian maupun keseluruhan populasi penduduk, yang karena faktor geografis, demografis, sosial, ekonomi, dan politik - memiliki preferensi yang sama dan/atau berbeda terhadap barang dan jasa publik.

Pertanyaan untuk apa melahirkan preposisi: pelayanan publik melayani kepentingan publik (public interest). Apakah kepentingan publik itu? Box (2007: 585-598) menggunakan tiga perspektif untuk menggambarkan kepentingan publik, yakni perspektif subtantive, perspektif aggregative, dan perspektif process. Perspektif subtantive meyakini bahwa kepentingan publik itu mengandung nilai-nilai yang bisa diterima beragam kelompok. Perspektif aggregative menganggap kepentingan publik merupakan agregasi nilai-nilai individu dan kelompok. Perspektif process menganggap kepentingan publik berisi nilai-nilai yang terus berevolusi melalui dialog di ranah governance. Lebih jauh Box (2007: 585-598) mengatakan bahwa dinamika kontemporer yang terjadi di masyarakat, pengetahuan publik (seluruh informasi yang diperoleh masyarakat melalui beragam media), dan variabel waktu sangat mempengaruhi content ketiga perspektif di atas dalam memahami sosok kepentingan publik.

Argumentasi yang cukup komprehensif tentang kepentingan publik dipaparkan Alexander (2002) yang menunjukkan bahwa makna kepentingan publik sangat variatif tergantung kepada sudut pandang yang digunakan seseorang (lihat, Tabel 1). Di lihat dari substansinya, basis kepentingan publik bisa berasal dari agregasi preferensi individu dan kelompok. Ia juga bisa berasal dari nilai-nilai yang diyakini kelompok, termasuk negara, sebagai nilai yang diterima seluruh anggota kelompok. Ia juga bisa berasal dari konsepsi tentang hak-hak individu. Di lihat dari prosedurnya, basis kepentingan publik bisa hak-hak individual dan/atau hasil intersubjektivitas individu dalam proses yang dialogis. Sementara itu, Bozeman (2007: 99) mendefenisikan kepentingan publik sebagai an ideal, public interest refers to those outcomes best serving the long-run survival and well-being of a social collective construed as a "public".

Penulis sendiri cenderung memahami kepentingan publik sebagai titik kompromi nilai-nilai (values) dan norma-norma (norms) yang hidup, berkembang, dan diyakini institusi negara, institusi pasar, dan institusi masyarakat sipil. Dalam konteks ini, nilai-nilai publik, meminjam argumentasi Bozeman (2007: 132), merupakan konsensus normatif tentang hak dan kewajiban warga negara kepada masyarakat, negara, dan prinsip-prinsip dasar yang melandasi perputaran roda dan kebijakan pemerintah. Mengapa nilai-nilai publik dianggap sebagai hasil kompromi? Dewasa ini hampir tidak ada institusi sosial-politik, baik pada level lokal, nasional, dan global, yang memonopoli produksi nilai-nilai dan norma-norma publik. Setiap negara, terutama yang mengaplikasikan sistem demokrasi, 
membuka peluang bagi setiap individu, kelompok, dan organisasi untuk menggugat nilai-nilai dan normanorma publik yang diyakini sepihak oleh rezim sebagai nilai dan norma publik. Selain itu, di setiap negara demokrasi, pemerintahan perwakilan memungkinkan nilai-nilai dan normanorma publik diperdebatkan secara terbuka. Kontestasi perdebatan ini memungkinkan terjadinya titik kompromi beragam kelompok kepentingan dalam memandang substansi nilai-nilai dan norma-norma publik. Meskipun ada unsur hegemoni dan dominasi dalam perdebatan itu, tetapi sistem demokrasi mampu memastikan hegemoni dan dominasi itu tidak melanggar prinsip-prinsip kemanusiaan dan hak asasi manusia yang menjadi landasan filosofis dan ideologis nilai-nilai dan norma-norma publik di beragam belahan dunia.

Anasir kedua dan ketiga, yang melayani dan sumber legitimasinya. Ketika kaum aristokrat masih berkuasa, mereka menggunakan orang per orang sebagai pelayan masyarakat yang dilegitimasi lembaga-lembaga aristokrasi. Tetapi, lembaga aristokrasi tak bertahan lama. Pesatnya perkembangan ilmu pengetahuan dan dinamika ekonomi-politik masyarakat menghasilkan kebutuhan-kebutuhan dan aspirasi-aspirasi baru. Inggris, Jepang, Arab Saudi, Malaysia, adalah sebagian contoh terjadinya kompromi antara lembaga aristokrasi dengan perubahan sosial-politik masyarakat setempat. Lembaga aristokrasi bersanding dengan lembaga-lembaga pemerintahan modern yang mengakar dalam konsep Trias Politika. Salah satu bentuk kompromi itu adalah penggunaan birokrasi publik sebagai aktor pelayan masyarakat yang sumber legitimasinya berasal dari konstitusi dan peraturan perundang-undangan yang berlaku.

Sementara itu, di beberapa negara modern yang tidak memiliki akar aristokrasi seperti di Amerika Serikat, gagasan tentang birokrasi publik bermula tatkala merebaknya urbanisasi, industrialisasi, dan pertumbuhan populasi penduduk yang melahirkan aspirasi, kebutuhan, dan tantangan-tantangan baru yang harus dihadapi institusi pemerintah. Dalam latar seperti inilah Woodrow Wilson mendesakkan pemisahan antara konsep politik (politics) dan konsep administrasi (administration), baik pada level teoritik maupun level praktek penyelenggaraan negara (Raadschelders, 2003). Dari sini, bermunculan kajian-kajian tentang bagaimana seharusnya roda pemerintahan, khususnya birokrasi publik, dijalankan. Mulai dari POSDCORB-nya Luther Gulick, konsep the Administrative State-nya Waldo, the Reinventing Governmentnya David Osborne \& Ted Gaebler, serta konsep Clean and Good Governance yang didesakkan lembaga-lembaga international semisal World Bank, ADB, IMF, dan sebagainya.

Di Indonesia, pihak yang terlibat dalam pelayanan publik tidak hanya institusi pemerintah. Undang-undang Nomor 25 Tahun 1999 tentang Pelayanan Publik menegaskan bahwa penyelenggara pelayanan publik bisa berbentuk institusi penyelenggara negara, korporasi, lembaga independen 
yang dibentuk berdasarkan undangundang untuk melakukan kegiatan pelayanan publik, atau badan hukum lainnya yang dibentuk semata-mata untuk kegiatan pelayanan publik (Pasal 1).

Tabel 1.

Konsep dan Aplikasi Kepentingan Publik

\begin{tabular}{|c|c|c|c|c|c|}
\hline Focus & Approach & $\begin{array}{c}\text { Interest } \\
\text { Base }\end{array}$ & Theory & Perspective & Application \\
\hline \multirow{5}{*}{ Subtantive } & Aggregative & $\begin{array}{l}\text { Individual } \\
\text { values/ } \\
\text { preferences }\end{array}$ & Utilitarianism & Objective & $\begin{array}{l}\text { Social welfare } \\
\text { function, } \\
\text { benefit-cost } \\
\text { analysis }\end{array}$ \\
\hline & Aggregative & $\begin{array}{l}\text { Individual } \\
\text { and/or } \\
\text { groups }\end{array}$ & $\begin{array}{l}\text { Modified } \\
\text { utilitarianism }\end{array}$ & Subjective & $\begin{array}{l}\text { Multi-objective } \\
\text { evaluation }\end{array}$ \\
\hline & Unitary & $\begin{array}{l}\text { Collective } \\
\text { community }\end{array}$ & Communitarianism & $\begin{array}{l}\text { Value-based } \\
\text { cultural } \\
\text { ideological }\end{array}$ & $\begin{array}{l}\text { Political/ } \\
\text { administrative, } \\
\text { compatibility } \\
\text { with values and } \\
\text { norms }\end{array}$ \\
\hline & Unitary & Polity, state & $\begin{array}{l}\text { Etatism, } \\
\text { constitution, law }\end{array}$ & Objective & $\begin{array}{l}\text { Legal/ } \\
\text { adjudication } \\
\text { compatibility } \\
\text { with state } \\
\text { interest }\end{array}$ \\
\hline & Deontic & $\begin{array}{l}\text { Individual } \\
\text { (planning) } \\
\text { rights }\end{array}$ & $\begin{array}{l}\text { Liberal- } \\
\text { democracry, } \\
\text { constitution, law }\end{array}$ & Objective & $\begin{array}{l}\text { Administrative- } \\
\text { legal review, } \\
\text { compatibility } \\
\text { with planning } \\
\text { rights }\end{array}$ \\
\hline \multirow[t]{2}{*}{ Procedural } & Deontic & $\begin{array}{l}\text { Individual } \\
\text { rights }\end{array}$ & $\begin{array}{l}\text { Liberal } \\
\text { individualism }\end{array}$ & Objective & $\begin{array}{l}\text { Legal/ } \\
\text { adjudication } \\
\text { compatibility } \\
\text { with individual } \\
\text { procedural } \\
\text { rights }\end{array}$ \\
\hline & Dialogical & $\begin{array}{l}\text { Stakeholder } \\
\text { groups }\end{array}$ & $\begin{array}{l}\text { Madisonian } \\
\text { liberlism } \\
\text { communicative } \\
\text { practice }\end{array}$ & Intersubjective & $\begin{array}{l}\text { Political } \\
\text { discourse }\end{array}$ \\
\hline
\end{tabular}

Sumber: Alexander (2002: 229).

Dewasa ini, yang berpotensi menjadi pelayan publik itu tidak hanya negara/pemerintah, tetapi juga individu, kelompok masyarakat sipil, dan/atau korporasi swasta. Sumber legitimasinya adalah demokrasi. Per defenisi, demokrasi adalah sekumpulan nilai. Tanpa nilai-nilai ini, lembaga-lembaga demokrasi ini menjadi tidak berarti (Waldo, 1952: 81103). Demokrasi, dengan variasi kelembagaannya, mendorong dan mengabsahkan individu dan kelompok sebagai pelayan publik yang melayani kepentingan publik. 
Anasir keempat, bentuk aktivitas pelayanan. Jauh sebelum Revolusi Industri terjadi, mayoritas perekonomian dunia didominasi aktivitas pertanian, peternakan, perdagangan, dan kegiatan industri rumah tangga dengan prinsip tukarmenukar (Erikson, 2004: 85). Pasca Revolusi Industri, bentuk aktivitas perekonomian semakin beragam. Prinsip tukar-menukar berganti menjadi jual-beli. Institusi negara/pemerintah yang diawal perkembangan pemikiran teoritik ekonomi diharapkan berfungsi sebatas penjaga malam memperoleh momentum terlibat lebih jauh dalam aktivitas perekonomian karena fakta inefisiensi prinsip-prinsip pasar dalam menciptakan pertumbuhan, pemerataan, dan keadilan sosial. Bentuk aktivitas pelayanan yang menjadi domain area birokrasi publik bisa sangat beragam, mulai dari membuat undang-undang, menyelenggarakan pendidikan tinggi, atau menyediakan jaminan sosial bagi setiap warga negaranya. Gagasan ini berakar dalam pemikiran ekonomi Jhon M. Keynes yang menghendaki campur tangan pemerintah dalam aktivitas perekonomian.
Pelayanan publik sebetulnya melibatkan banyak pihak. Di lihat dari kepemilikan sumberdayanya, pelayanan publik itu merupakan sebuah garis lurus yang memiliki dua titik (lihat, Gambar 1). Di salah satu ujung garis, ada pelayanan publik yang sumberdayanya berasal dari sektor swasta murni. Di ujung garisnya satunya adalah pelayanan publik yang sumberdayanya berasal publik secara langsung atau melalui lembaga pemerintah yang merepresentasikan publik. Sedangkan garis putus-putus yang memotong garis lurus tersebut merepresentasikan batas wilayah antara swasta murni dan publik murni. Ia merupakan wilayah terjadinya kemitraan publik-swasta (public private partnership) dalam pengelolaan pelayanan publik. Tetapi, dalam logika Christensen dan Pallesen (2008: 19), garis putus-putus ini bisa juga diterjemahkan sebagai wilayah masyarakat sipil. Asal sumberdaya ini menentukan siapa yang memiliki dan mengelola pelayanan publik tersebut. Seluruh bentuk pelayanan publik yang ada bisa dipetakan posisinya dalam garis lurus ini berdasarkan proporsi kepemilikan sumberdaya.

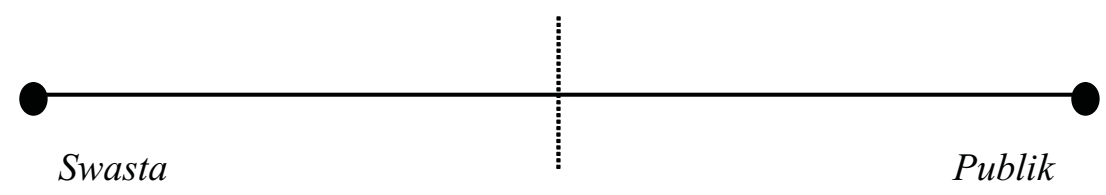

Public-private patnership

Gambar 1.

Pelayanan: swasta versus publik 
Pola lain yang bisa digunakan untuk menjelaskan bentuk aktivitas pelayanan publik adalah melalui tipe organisasi yang melaksanakannya. Menurut Doherty \& Horne (2002: 4), organisasi pelayanan publik bisa dibedakan menjadi beberapa tipe, yakni: organisasi kedermawanan sosial (social charity), swasta murni, kerjasama swasta dan publik, kontrak, publik tetapi dikelola atas dasar kompetisi, dan publik tanpa kompetisi (lihat, Tabel 1). Konseptualisasi yang diajukan Doherty dan Horne (2002) menunjukkan bahwa pelayanan publik tidak selalu berarti pelayanan yang dilaksanakan pemerintah. Aktivitas yang dilakukan aktor-aktor nonpemerintah, baik itu para pelaku pasar dan asosiasi masyarakat sipil, juga merupakan aktivitas pelayanan publik. Sebab, dalam derajat tertentu, tindakan para pelaku pasar dan asosiasi masyarakat sipil bersinggungan kebutuhan sebagian dan/atau keseluruhan kebutuhan penduduk, baik sebagai individu maupun kelompok. Karena, dalam bahasa Phillip Kottler, every organization is swimming in a sea of publics (Drucker, 2005: 76).

Tabel 2.

Tipe-tipe Organisasi

\begin{tabular}{|l|l|}
\hline \multicolumn{1}{|c|}{ Tipe Organisasi } & \multicolumn{1}{c|}{ Contoh } \\
\hline Kedermawanan sosial (social charity) & TIFA Foundation, WARSI, Birdlife \\
\hline Swasta murni (fully private) & PT. Kramayuda Tiga Berlian \\
\hline Kerjasama swasta dan publik & Transjakarta, Transjogja, dan Transmusi \\
\hline Swasta, tapi diatur publik & Distribusi pupuk bersubsidi \\
\hline Kontrak & Pengadaan barang dan jasa pemerintah \\
\hline $\begin{array}{l}\text { Publik, tapi dikelola atas dasar } \\
\text { kompetisi }\end{array}$ & $\begin{array}{l}\text { PT. Garuda Indonesia, Hotel Swarna Dwipa } \\
\text { Palembang }\end{array}$ \\
\hline Publik tanpa kompetisi & PT. Kereta Api Indonesia \\
\hline
\end{tabular}

Sumber: Doherty \& Horne (2002: 4). Dimodifikasi seperlunya oleh penulis

Laing (2003) membangun tipologi pelayanan publik berdasarkan manfaat yang diterima dan penilaian yang masyarakat. Menurut tipologi ini, ketika aktivitas pelayanan publik lebih banyak mengandung kepentingankepentingan private (public benefits), maka penilaian warga negara lebih dominan dalam mempengaruhi isi pelayanan publik (misalnya, pembangunan perumahan). Sebaliknya, jika aktivitas pelayanan tersebut melayani kepentingan masyarakat luas (social benefits), maka pertimbangan para pelayan publik tentang isi pelayanan lebih dominan (misalnya, jasa yang diberikan kepolisian). 
Social benefits dominant

Customs \& Criminal

Excise justice

Profesional judgement dominant

Sumber: Laing (2003: 438)

Terakhir, Fisher (1998: 5-6) mengkategorikan pelayanan publik ke dalam beberapa kelompok: pertama, pelayanan yang dibutuhkan untuk mengembangkan, menginformasikan, dan memproteksi individu (misalnya, pendidikan, kesehatan, dan keamanan). Kedua, pelayanan yang mendukung dan mendorong perkembangan sektor swasta (misalnya, infrastruktur jalan, regulasi, energi). Ketiga, pelayanan dan mendukung dan mendorong infrastruktur kebudayaan (misalnya, jasa penyiaran, festival budaya). Keempat, pelayanan yang terkait dengan redistribusi kesejahteraan (misalnya, pelayanan pajak, jaminan sosial).

\section{PRAXIS PELAYANAN PUBLIK}

Di Inggris dan Amerika Serikat, terutama sejak neoliberalisme memegang tampuk kekuasaan politik di kedua negara tersebut pada tahun 1980-an, pendulum pelayanan publik bergerak dari arah publik (negara) ke swasta. Di Inggris, pendulum digerakkan Margareth Hilda Thatcher dan Amerika Serikat oleh Ronald Reagen dengan Reagenomics-nya. Langkah Margareth Hilda Thatcher di Inggris dilanjutkan Tony Blair. Sedangkan jejak Ronald Reagen diteruskan Bill Clinton di Amerika Serikat (Steger dan Roy, 2010). Neoliberalisme meyakini pasar lebih baik ketimbang institusi

Tabel 3.

Pelayanan Publik

\author{
Public benefits dominant \\ Health care Public Public \\ transport housing
}

Consumer judgment dominant

negara/pemerintah sebagai penyedia barang dan jasa. Ia menyukai pemerintahan yang dijalankan dengan nilai-nilai kewirausahaan (kompetitif, self-interest, dan desentralisasi) sebagaimana dikemas dalam konsep new public management (Lane, 2000; Pollit, 2003). Formula DLP (deregulasi, liberalisasi, dan privatisasi) menjadi strategi ampuh untuk mereformasi dan menjalankan pelayanan publik.

Di Cina, organisasi pelayanan publik merujuk kepada beragam organisasi pemerintah yang menjalankan fungsi-fungsi publik dan sosial (Tang dan Lo, 2009). Sebelum 1998, birokrasi pemerintah yang memiliki personil sebanyak 33 juta orang dan tersebar di lembaga-lembaga pemerintah seperti perusahaan negara (jingji shiti), lembaga-lembaga intermediary (zhongjie jigou), organisasi sosial (shehui tuanti), dan unit-unit fungsional (shiye danwei). Total gaji seluruh pegawai pemerintah ini menelan 40 persen dari anggaran pemerintah.

Pasca 1998, Cina melakukan serangkaian reformasi di sektor publik. Reformasi ini berbentuk downsizing birokrasi publik, transfer fungsi-fungsi publik ke sektor swasta dan masyarakat sipil, mendorong kompetisi dan peran aktor-aktor swasta dalam pelayanan 
publik (Drewry dan Chan, 2001), memperkuat partisipasi masyarakat, meningkatkan transparansi (World Bank, 2007), berorientasi hasil, mempromosikan nilai publik dan akuntabilitas birokrasi (Chan dan Rosenbloom, 2010), dan restrukturisasi perekonomian negara dalam merespon integrasi perekonomian dunia melalui pasar bebas untuk mewujudkan a socialist market economy (Christensen, Lisheng, dan Painter, 2008).

Di Malaysia, hingga saat ini pelayanan publik tetap menjadi domain pemerintah. Tetapi, sejak 1997, pemerintah Malaysia melakukan serangkaian reenginering di sektor publik. Mereka menggunakan Total Quality Management (TQM), MS ISO9000, e-government. Mereka juga memproduksi serangkaian kebijakan deregulasi dan privatisasi, membenahi tata kelola pemerintahan agar lebih akuntabel, berbasis nilai, dan etika. Reenginering sektor publik di Malaysia menekankan nilai efisiensi, berorientasi hasil dan kebutuhan pelanggan, akuntabilitas, fairness dan integritas (Karim, 1999). Malaysia mengaplikasikan key performance indicators (KPI) untuk memperbaiki inefisiensi dan akuntabilitas pada level negara bagian (Halid, 2010).

Di benua Afrika, fenomena pelayanan publik sangat kompleks. Dari 56 negara di benua ini, sebagian besar merdeka sebelum tahun 1960-an, kecuali Mesir, Ethiopia, Afrika Selatan, dan Liberia. Negara-negara ini memiliki karakteristik yang sama, yakni: sedang bergulat dengan nationbuilding, termasuk dalam kategori negara miskin, perekonomian negara bergantung kepada pertanian, dan lembaga politik dan administrasi pemerintahan yang belum stabil. Sistem administrasinya melanjutkan apa yang sudah dibangun pemerintahan kolonial, terutama Inggris yang memiliki negara jajahan paling banyak. Dewasa ini, negara-negara miskin Afrika dihadapkan dengan persoalan kepemimpinan politik, korupsi, rendahnya kapasitas kelembagaan, etika dan manajemen pelayanan publik. Meskipun institusi negara tetap bertanggung jawab dalam menyediakan pelayanan publik dasar bagi para penduduk (mengumpulkan pajak, membangun jalan, regulasi, pelayanan pendidikan dan kesehatan, dan lain-lain), secara perlahan mereka menjalankan serangkaian reformasi pelayanan publik melalui privatisasi dan downsizing dalam rangka mendorong pelayanan publik yang misson-driven, akuntabel dan kompetitif. Mereka juga menerapkan NPM, tetapi gagal karena pengaruh institusi-institusi informal (Besley \& Ghatak, 2007), konteks sosial-politik yang kompleks dan minimnya pengalaman dengan beberapa elemen NPM seperti transparansi, akuntabilitas, dan management by results (Jreisat, 2010: 612-631).

Di Jepang, pelayanan publik tetap didominasi birokrasi pemerintah pusat dan pemerintah daerah yang bersifat elitis (Kim, 2002), semakin politis dan saling ketergantungan (Hill dan Fujita, 2000). Reformasi pelayanan publik dimulai pada 1983. Isu utamanya adalah desentralisasi, privatisasi, reorganisasi dan restrukturisasi, efisiensi anggaran, transparansi, dan partisipasi warga 
(Thosiyuki, 1999: 215-228). Menurut Tanigaki (2001: 83-93), reformasi pelayanan publik di Jepang, khususnya di era Hashimoto (1996-1997), gagal memperbaiki sistem manajemen kepegawaian dan akuntabilitas pelayanan publik.

Di kawasan Timur Tengah, pelayanan publik sebagian besar didominasi birokrasi negara. Sebagian negara-negara di kawasan ini berbentuk republik (Suriah, Lebanon, Mesir, Yaman, Irak). Sebagian lagi berbentuk monarkhi (Arab Saudi, Oman, Unit Emirat Arab, Qatar) dan monarkhi konstitutional (Kuwait, Bahrain). Meskipun negara-negara ini kaya, tetapi mereka gagal memenuhi pelayanan dasar bagi warga negaranya yang terangkum dalam konsep MDGs (UNDP, 2009). Mereka juga gagal menjalankan proses modernisasi (Jreisat, 2006). Dalam konteks negaranegara berbentuk monarkhi, reformasi pelayanan publik terkesan lambat dan tambal sulam karena minimnya faktor ekonomi-politik yang memaksa elitelit monarkhi untuk melakukan reformasi pelayanan publik secara holistik. Kondisi ini muncul akibat kuatnya tradisi yang menopang keluarga kerajaan (Common, 2008: 177-193). Sedangkan, dalam kasus negara-negara berbentuk republik, kegagalan konstitusi melahirkan instabilitas sosial-politik yang menyebabkan pemerintah tidak bisa berkonsentrasi untuk memenuhi pelayanan publik kepada masyarakat (UNDP, 2009).

Di Indonesia, aktivitas pelayanan publik juga didominasi negara. Pasca Pemilu 2009, rezim
SBY-Boediono secara bertahap melakukan reformasi birokrasi publik. Kebijakan desentralisasi yang sudah dijalankan sejak 1999 cukup menggembirakan meskipun tidak bisa dikatakan berhasil seratus persen. Desentralisasi melahirkan fenomena semangat kedaerahan yang sempit, politik uang, transfer korupsi dari pusat ke daerah, transformasi identitas kultural, dan persoalan lingkungan hidup (Erb, Sulistiyanto, dan Faucher, 2005). Selain desentralisasi, rezim SBY-Boediono juga sangat serius memerangi korupsi, memprivatisasi perusahaan negara, dan memperkuat kapasitas kelembagaan institusi birokrasi publik.

Di era SBY, pelayanan publik yang terkait dengan kebutuhan dasar (basic needs) manusia semakin menguat. Pendidikan, kesehatan, dan kemiskinan adalah isu-isu penting yang diprioritaskan rezim SBY. Program PNPM, misalnya, menjadi ikon keberpihakan resim SBY terhadap pemberdayaan masyarakat. Di samping itu, isu pemberantasan korupsi yang diusung rezim SBY memiliki dampak positif terhadap wajah pelayanan publik di Indonesia. Para pejabat negara, baik birokrat maupun politisi, semakin berhati-hati menjalankan peran dan tugas mereka sebagai pelayan publik.

Karena institusi birokrasi memiliki peran penting dalam pelayanan publik, rezim SBY tampak lebih serius dengan program reformasi birokrasi publik yang sudah direalisasikan di beberapa lembaga negara/pemerintah pusat. Meskipun program reformasi birokrasi publik ini 
cenderung mengedepankan pendekatan remenurasi sebagai obat patologi birokrasi, tetapi sedikit banyak ia mempengaruhi kualitas perbaikan pelayanan publik yang dikelola institusi birokrasi publik.

Pada level daerah, pelayanan publik menunjukkan pergeseran yang positif. Sebagian daerah dianggap berhasil menjalankan otonomi daerah yang berpihak kepada pelayanan publik yang lebih kepada masyarakat. Kondisi ini dipicu mekanisme pilkada yang memaksa elit-elit politik berinteraksi langsung dengan para pemilih. Meskipun mayoritas para pemilih pilkada dianggap pemilih emosional, tetapi dalam derajat tertentu mereka mampu menilai janji-janji politik elit-elit politik yang berpihak kepada kepentingan masyarakat. Sedangkan sebagian lagi dianggap kurang berhasil mengelola kewenangan yang dimilikinya.

Narasi di atas menunjukkan bahwa institusi negara tetap mendominasi pelayanan publik di banyak negara. Meskipun ada kecenderungan untuk menggeser pengelolaan pelayanan publik dari negara ke pasar atau dari pola hirarki ke pola mekanisme pasar. Tetapi, pergeseran ini tidak menunjukkan bahwa institusi pasar lebih baik dari institusi negara dalam hal penyampaian pelayanan publik. Meskipun pelayanan publik non-profit memiliki pasar tersendiri sebagaimana layaknya aktivitas pelayanan yang berorientasi pasar (Drucker, 2005: 77), tetapi tidak berarti ia harus mengimpor 'segala sesuatunya' dari sektor pasar. Dalam konteks ini, Hughes (2003: 282) mengatakan bahwa pasar dan birokrasi publik sesungguhnya saling membutuhkan satu sama lain. Pasar tidak akan pernah bisa menggantikan birokrasi publik, begitu pula sebaliknya.

\section{E. KARATERISTIK UNIVERSAL PELAYANAN PUBLIK}

Praxis pelayanan publik dari satu negara ke negara hampir bisa dipastikan berbeda seratus persen. Ia dipengaruhi banyak faktor yang kompleks yang lahir dari lingkungan sosial, ekonomi, politik, dan budaya yang beragam. Sebagai contoh, hasil studi Ramanie, Alam, dan Teicher (2008) tentang NPM di Asia menunjukkan bahwa kegagalan dan keberhasilan aplikasi NPM dipengaruhi oleh sejarah politik, partai politik, kondisi ekonomi makro, budaya politik, peran lembagalembaga internasional, konfigurasi masyarakat sipil, dan target yang ingin dicapai. Tetapi, keragaman itu sesungguhnya hanya nampak dipermukaan saja. Substansinya adalah sama. Dengan mengedepankan substansi, karakteristik universal pelayanan publik dapat dikonstruksi.

Karakteristik universal pelayanan publik itu dapat dijelaskan sebagai berikut: pertama, pelayanan publik berorientasi kepentingan publik. Maksudnya, keputusan-keputusan yang diproduksi otoritas publik yang terkait dengan pelayanan publik harus mendahulukan kepentingan publik (O'Toole, 2006: 3) dan nilai-nilai publik (Bozeman, 2007). Perbedaan yang terjadi antar hanyalah soal apa dan bagaimana mendefenisikan kepentingan dan nilai-nilai publik 
tersebut.

Di negara-negara demokrasi, pelayanan publik memiliki peran dan tanggung jawab untuk menegakkan nilai-nilai demokratis dan memastikan pemenuhan hak-hak warga negara (Hamilton, 2007: 14). Pelayan publik tidak hanya menyampaikan barang dan jasa kepada warga negara sebagai pelanggan (customer). Mereka juga menyampaikan demokrasi (Denhardt \& Denhardt, 2007: xi). Di negaranegara berbentuk kerajaan seperti di kawasan Timur Tengah, pelayanan publik harus seiring sejalan dengan kepentingan publik yang didominasi kepentingan ekonomi-politik keluarga kerajaan;

Kedua, konsekuensi ciri pelayanan publik berorientasi kepentingan publik adalah para pelayan publik tidak boleh bebas nilai (value free). Ia harus berpihak, yakni berpihak kepada kepentingan publik. Sebab, para pelayan publik memiliki peran sebagai the guardian of public interest. Bagaimana konsepsi the guardian of public interest ini diterjemahkan sangat tergantung pada pilihan ideologi rezim, desain sistem politik, dan dinamika sosial, ekonomi, politik yang berkembang di suatu negara. Di negara-negara liberal, negara minimalis merupakan sosok the guardian of public interest yang diidam-idamkan. Di negara-negara yang memiliki akar sosialisme ( mis alnya, Jerman) negara kesejahteraan merupakan tafsir ideal atas fungsi negara sebagai the guardian of public interest.

Ketiga, proses pelayanan publik itu harus partisipatif dan memberdayakan, fast, flexible, dan friendly (Milner, 2002: 15), ekonomis (efisien, efektif, dan produktif), berkeadilan sosial dan ekologis (Baxter, 2005; Low \& Gleeson, 1998), serta akuntabel secara horisontal, vertikal, societal (Mainwaring \& Welna, 2003), internal dan eksternal (Sperling, 2009), responsif dan transparan. Ciri ketiga ini merupakan konsekuensi logis karakter pelayanan publik yang berorientasi kepentingan publik, berlandaskan nilai-nilai publik, dan bersifat value free. Ciri ketiga ini menekankan arti penting pelayanan publik sebagai proses yang nonmekanis, tetapi relasi dinamis antara manusia dengan kelompoknya, manusia dengan alam sekitarnya, dan manusia dengan struktur-stuktur ekonomi-politik yang dibentuk dalam rangka pengaturan kehidupan bersama.

Keempat, tindakan para pelayan publik mempertimbangkan etika tertentu (Lewis \& Gilman, 2005: 22). Etika adalah seperangkat moral. Nilainilai moral tak bisa dihilangkan dari proses pelayanan publik karena aktivitas ini tetap menempatkan manusia sebagai pelaku utamanya. Meskipun peran manusia sebagai pelayan publik diatur dalam kerangka sistem tertentu mekanis, tetapi ia tetap tidak bisa menghilangkan keberadaan nilai-nilai moral yang akan menjadi lem perekat beragam komponen dalam sistem pelayanan publik.

Kelima, sistem dan proses pelayanan publik dibangun atas dasar aturan, hukum, dan kesepakatan tertentu. Apakah dasar aturan, hukum dan kesepakatan ini dibuat atas prinsip- 
prinsip demokratis atau tidak akan sangat ditentukan bentuk negara dan/atau bentuk pemerintahan yang berlaku di negara-negara tersebut. Negara-negara modern, apakah itu berbentuk republik, monarki absolut, atau monarki konstitutional, membutuhkan sistem dan kelembagaan pelayanan publik.

Dalam konteks negara, pelayanan publik harus berbasis hukum positif karena ia bagian dari penyelenggaraan fungsi-fungsi pemerintahan yang berlandaskan rule of the law. Keberadaan aturan hukum ini tidak hanya dimaksudkan untuk memenuhi aspek legalitas pelayanan publik yang dilakukan institusi negara, tetapi bagian tak terpisahkan dari pemenuhan prinsip legitimasi politik. Hukum yang mengatur pelayanan publik merupakan produk proses politik yang dibuat lembaga-lembaga politik yang anggotanya dipilih rakyat sebagai pemilik sah kekuasaan. Pelayanan publik yang berlandaskan hukum sama artinya dengan pelayanan publik memiliki kekuatan legitimasi.

Dalam konteks aktor-aktor nonnegara (para pelaku pasar dan masyarakat sipil), hukum positif ini tidak selalu dijadikan landasan penyampaian pelayanan publik. Meskipun institusi negara menyediakan seperangkat aturan untuk mengatur pelayanan publik yang diberikan institusi pasar dan masyarakat sipil, tetapi keberadaan aturan ini tak lebih hanya sebagai salah satu alternatif tindakan. Beberapa pelayanan publik yang diselenggarakan institusi pasar dan masyarakat sipil tidak berlandaskan kepada hukum positif, tetapi berlandaskan prinsip trust.

\section{F. PENUTUP}

Hari ini, penulis kira, perdebatan teoritik tentang pelayanan publik terpusat pada persoalan pergeseran new public management ke governance, dari market-oriented ke citizensoriented. Pendulum ini tentu akan bergerak terus seiring dengan perubahan zaman. Tetapi, pendulum itu sendiri akan terikat pada satu titik, yakni: hakikat pelayanan publik yang bisa dijelaskan dengan menjawab pertanyaan siapa, untuk apa, dasarnya apa, dan apa dan bagaimana bentuknya.

Pelayanan publik itu ada karena adanya kebutuhan manusia yang harus dipenuhi. Karena kebutuhan manusia itu tak terbatas, maka konsepsi manusia tentang pelayanan publik itu sendiri akan seiring sejalan dengan perkembangan kebutuhan manusia. Lahirnya kebutuhan-kebutuhan baru manusia akan diiringi dengan inovasiinovasi baru dalam memenuhi kebutuhan baru tersebut. Proses ini akan terjadi secara dialektis sepanjang roda peradaban masih berputar. Tetapi, penulis meyakini, proses dialektis ini tidak akan banyak merubah karakter universal pelayanan publik sebagaimana dirumuskan diatas.

Meskipun karakteristik pelayanan publik itu bersifat universal, tetapi faktor-faktor kontekstual dan situasional yang diproduksi ruang dan waktu yang berbeda memberikan kontribusi terhadap wajah pelayanan publik di suatu negara. Pada titik ini, kontekstualisasi inilah yang perlu mendapat perhatian serius para 
pemerhati, ilmuwan, peneliti, dan praktisi pelayanan publik di Indonesia. Dengan gugusan ratusan pulau yang memiliki penduduk dengan konteks sosial, ekonomi, budaya, dan politik yang berbeda, kontekstualisasi ini merupakan tantangan tersendiri.

\section{DAFTAR PUSTAKA}

Alexander, E. R., 2002, The Public Interest in Planning: From Legitimation to Substantive Evaluation, dalam Planning Theory, Vol. 1 No. 3.

Besley, Timothy., \& Ghatak, Maitreesh, 2007, Reforming Public Service Delivery, dalam Journal of African Economies, Vol. 16, No. 1, hal. 127-156.

Box, Richard C., 2007, Redescribing the public interest, dalam The Social Science Journal, No. 44, hal. 585-598.

Bozeman, Barry, 2007, Public Values and Public Interest: Counterbalancing Economic Individualism, Washington, D.C.: Georgetown University Press.

Chan, Hon S., Rosenbloom, David H., 2010, Four Challenges to Accountability in Contemporary Public Administration: Lessons From the United States and China, dalam Administration \& Society, Vol. 42, No. 1, hal. 11-33

Christensen, Jørgen Grønnegaard., dan Pallesen, Thomas, 2008, Public employment trends and the organization of public sector tasks, dalam Derlien, HansUlrich., \& Peter, B. Guy., (eds.), 2008. The State at Work, Volume 2: Comparative Public Service Systems, Massachusset, Edward Elgar

Christensen, Tom., Lisheng, Dong, dan Painter, Martin, 2008 , Administrative reform in China's central government: how much 'learning from the West'?, dalam International Review of Administrative Science, Vol. 74, No. 3, hal.351-371.

Common, Richard, 2008 , Administrative Change in the Gulf: Modernization in Bahrain and Oman, dalam International Review of Administrative Sciences, Vol. 74, No. 2, hal. 177-193.

Doherty, Tony L., \& Horne, Terry, 2002, Managing Public Services - Implementing Changes: A Thoughtful Approach to the Practices Management, London: Routledge.

Drewry, Gavin., dan Chan, Che-Po, 2001, Civil Service Reform in the People's Republic of China: Another Mirage of the New Global Paradigm of Public Administration?, dalam International Review of Administrative Science, Vol. 67, No. 3, hal.461-478.

Drucker, Peter, 2005, Managing the Nonprofit Organization: Principle and Practices, New 
York: Harpers Collins.

Erb, Martibeth., Sulistiyanto, Priyambudi, dan Faucher, Carole, (Eds.), 2005 , Regionalism in Post-Suharto Indonesia, London: Routledge Curzon.

Erikson, Thomas Hylland, 2004, What is Anthropology?, London: Pluto Press.

Fisher, C. M., 1998, Resource Allocation in the Public Sector: Value, Priorities, and Market in the Management of Public Services, London: Routledge.

Franklin, Aimee L., 2001, Serving The Public Interest? Federal Experiences With Participation in Strategic Planning, dalam American Review of Public Administration, Vol. 31, No. 2.

Hill, Richard Child, dan Fujita, Kuniko, 2000, State Restructuring and Local Power in Japan, dalam Urban Studies, Vol. 37, No. 4, hal. 673-690.

Hughes, Owen E., 2003, Public $M a n a g e m e n t$ a $n d$ Administration: An Introduction, New York: Palgrave Macmillan.

Jreisat, Jamil E., 2006, The Arab World: Reform or Stalemate, dalam Journal of Asian and African Studies, Vol. 41, No. 5/6, hal.411-437

Jreisat, Jamil, 2010, Comparative
Public Administration and Africa, dalam International Review of Administrative Sciences, Vol. 76, No. 4, hal. 612-631

Karim, Muhammad Rais Abdul (Eds.), 1999, Reengineering the Public Service: Leadership and Change in an Electronic Age, Selangor Dahrul Ehsan: Pelanduk Publication.

Kim, Pan S., 2002, Civil Service Reform in Japan and Korea: Toward Competitiveness and Competency, d a $1 \mathrm{a} \mathrm{m}$ International Review of Administrative Sciences, Vol. 68, No. 3, hal. 389-403;

Laing, Angus, 2003, Marketing in the Public Sector: Towards a Typology of Public Service, dalam Marketing Theory, Vol. 3, No. 4, hal.427-445.

Lane, Jan-Erik, 2000, New Public Management, London: Routledge.

Lubienski, Christopher, 2003, Instrumentalist Perspectives on The "Public" in Public Education: Incentives and Purposes, dalam Educational Policy, Vol. 17, No. 4.

Masujima Thosiyuki, 1999, Evaluating Administrative Reform: An Insider's Report, dalam Social Science Japan Journal, Vol. 2, No. 2, hal. 215-228.

Pollit, Christopher, 2003, The Essential 
of Public Manager, Philadelphia: Open University Press.

Samaratunge, Ramanie., Alam, Quamrul., dan Teicher, Julian, 2008, The New Public Management Reform in Asia: A Comparison of South and Souteast Asian Countries, dalam International Review of Administrative Science, Vol. 71, No. 1, hal. 25-46.

Siti-Nabiha Abdul Halid, Improving the Service Delivery: A Case Study of a Local Authority in Malaysia, dalam Global Business Review, Vol. 11, No. 1, hal. 65-77.

Steger, Manfred B., dan Roy, Ravi K., 2010, Neoliberalism: A Very Short Introduction, New York: Oxford University Press.

Tang, Shui-Yan., dan Lo, Carlos WingHung, 2009. The Political Economy of Service Organization Reform in China: An Institutional Choice Analysis, dalam Journal of Public Administration Research and Theory, Vol. 19, hal. 731767

Tanigaki, Kunio, 2001, Reforming the Japanese Civil Service: Evaluation of the Hashimoto Reform, 1996-1997, dalam Japan and the World Economy, Vol. 13, hal. 83-93.

United Nations Development Programme, Arab Human
Development Report 2009: Challenge to Human Security in Arab World, New York: United $\mathrm{Nations}$ Development Programme.

Waldo, Dwight, 1952, Development of Theory of Democratic Administration, dalam The American Political Sciences Review, Vol. 46, No. 1, hal. 81103.

World Bank, 2007, China Public Services for Building the New Socialist Countryside, Report No. 40221-CN. Washington, D.C.: World Bank.

Peraturan Perundang-undangan Undang-Undang Nomor 25 Tahun 1999 tentang Pelayanan Publik. 


\section{Resensi Buku}

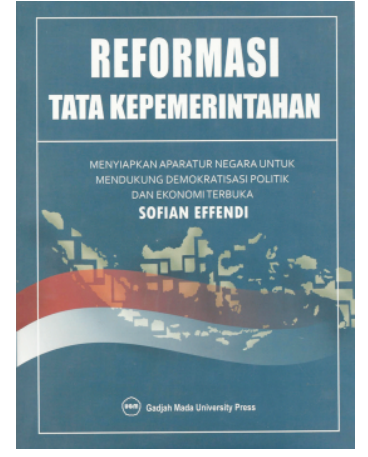

Judu; Buku

Penulis

Penerbit

Tahun Terbit

Tebal

Indonesia telah mengalami krisis multidimensi yang menyesakkan bagi seluruh sendi kehidupan. Krisis yang dimulai sejak lebih satu dasawarsa tersebut telah melemahkan stuktur ekonomi, struktur politik, struktur sosial dan lainnya. Saat itu Indonesia telah terpuruk dititik nadir setelah 32 tahun berada dalam "kemapanan" versi orde baru. Sejak saat itu bangsa yang dikenal dengan kesantunannya ini berusaha sekuat tenaga keluar dari kumkuman krisis. Sejak saat itu, reformasi menjadi langkah yang dipercaya untuk membantu bangsa ini keluar dari krisis.

Angin reformasi rupanya berhembus sampai kedasar negeri ini. Buktinya Undang-Undang Dasar Negara Republik Indonesia 1945 telah mengalami perubahan (Amandemen) sebanyak 4 (empat) kali. Sebagai imbasnya telah terjadi perubahan tata kepemerintahan di Indonesia. Perubahan tersebut setidaknya dapat digambarkan dalam tiga hal berikut ini: (1) perubahan sistem pemerintahan dari semi-presidensial ke arah presidensial; (2) pemberian desentralisasi kepada Pemerintah Daerah; dan (3) perubahan mendasar dalam perspektif ekonomi bangsa ke arah pasar bebas telah menghadapi ketiga perubahan yang besar tadi diperlukan dukungan sistem administrasi yang berkapasitas tinggi, transparan dan akuntabel (Effendi, 2010). Untuk itu reformasi administrasi mutlak dilakukan agar mampu memberikan dukungan yang maksimal terhadap prosesi reformasi. Dan salah satu agenda reformasi administrasi ini adalah reformasi aparatur negara untuk mewujudkan aparatur negara yang profesional, a-politis, bersemangat pelayanan, dan berwawasan global.

Buku ini diberi judul "Reformasi Tata Kepemerintahan: Menyiapkan Aparatur Negara untuk Mendukung Demokratisasi Politik dan Ekonomi Terbuka". Buku ini mengupas perjalanan dan mengungkap sisi-sisi yang belum tersingkap dalam reformasi tata pemerintahan yang berbasiskan hasil amandemen UUD 1945 dari sisi ilmiah. Juga memberikan gambaran langkah-langkah strategis dalam melakukan reformasi aparatur dan manajemen kepemerintahan. Dan yang terpenting adalah buku ini akan memberikan perspektif berbeda dalam memandang sebuah proses reformasi itu sendiri. 